\title{
Differences in Feeding Sites Induced by Root-Knot Nematodes, Meloidogyne spp., in Chickpea
}

\author{
Nicola Vovlas, Hava F. Rapoport, Rafael M. Jiménez Díaz, and Pablo Castillo
}

First author: Istituto per la Protezione delle Piante, Sezione di Bari: Nematologia Agraria, Consiglio Nazionale delle Ricerche, (C.N.R.), Via G. Amendola 165/A, 70126 Bari, Italy; second and fourth authors: Instituto de Agricultura Sostenible (IAS), Consejo Superior de Investigaciones Científicas (CSIC), Apdo. 4084, 14080 Córdoba, Spain; and third author: IAS-CSIC and Escuela Técnica Superior de Ingenieros Agrónomos y de Montes, Universidad de Córdoba, Apartado 3048, 14080 Córdoba, Spain.

Accepted for publication 8 December 2004.

\begin{abstract}
Vovlas, N., Rapoport, H. F., Jiménez Díaz, R. M., and Castillo, P. 2005. Differences in feeding sites induced by root-knot nematodes, Meloidogyne spp., in chickpea. Phytopathology 95:368-375.

Root-knot nematodes (Meloidogyne spp.) are sedentary, obligate endoparasites in plants, where they induce specialized feeding sites. The feeding sites act as strong metabolic sinks to which photosynthates are mobilized. The histopathological modifications in the nematode-induced feeding sites of artificially inoculated chickpea cv. UC 27 were qualita-

gyne species. Nevertheless, neither the number of giant cells in the feeding site (averaging four to six) nor the area of individual giant cells was influenced by nematode species or isolate. However, the number of nuclei per giant cell was significantly smaller, and the maximum diameters of nuclei and nucleoli were significantly greater, in giant cells induced by $M$. artiellia isolates than in those induced by $M$. arenaria, $M$. incognita, or $M$. javanica. In a second experiment, $M$. artielliainduced giant cells in faba bean and rapeseed also contained a small number of large nuclei.
\end{abstract} tively and quantitatively compared using five isolates of $M$. artiellia and one isolate each of $M$. arenaria, $M$. incognita, and $M$. javanica. All Meloidogyne isolates infected chickpea plants, but root gall thickening was significantly less for M. artiellia isolates than for the other Meloido-
Additional keywords: Brassica napus var. oleifera, Cicer arietinum, food legumes, histopathology, Vicia faba.
Sedentary endoparasitic root-knot nematodes of the genus $\mathrm{Me}$ loidogyne are among nature's most successful parasites. These nematodes infect thousands of different herbaceous and woody monocotyledonous and dicotyledonous plants and cause serious losses to numerous agricultural crops worldwide $(13,28)$. Parasitism by root-knot nematodes is characterized by the establishment of permanent feeding sites comprised of giant cells in the cortex, endodermis, pericycle, and vascular parenchyma of the host root tissues. These feeding sites are sinks for the plant photosynthates, and they thus impair plant growth and development. In addition, deformation and blockage of vascular tissues at the feeding sites limit translocation of water and nutrients, further suppressing plant growth and crop yield (20). Management of root-knot nematodes has primarily depended on nematicides and resistant cultivars. Use of nematicides is questioned because of their short-term efficacy as well as their potentially negative impact on the environment and human health. Therefore, there is a need for new root-knot nematode management strategies, which are likely to require better understanding of interactions between the plant and the nematode.

Infection by root-knot nematodes begins with penetration of the root tissues by the second-stage juvenile (J2) at the zone of root elongation. The nematode then migrates in the apoplast, ultimately reaching the vascular cylinder where giant cells are induced.

Corresponding author: P. Castillo; E-mail address: ag1cascp@uco.es

* The $\boldsymbol{e}$-Xtra logo stands for "electronic extra" and indicates that the online version contains supplemental material not included in the print edition. Figures 1, 3, 4, and 5 are in color online.

DOI: 10.1094/PHYTO-95-0368

(C) 2005 The American Phytopathological Society
Thereafter, the $\mathrm{J} 2$ undergo three molts to develop into adults. Female adults remain sedentary, producing large egg masses and galls, while male adults migrate to the soil. Nematode growth and reproduction depend on the induction of giant cells, which are believed to be their only feeding site. Cytological observations indicate that those giant cells are multinucleate with enlarged nuclei and nucleoli, the multinucleate status resulting from karyokinesis without subsequent cytokinesis (17). Compared with normal cells, giant cells also show increased cytoplasmic density, loss of normal vacuolation, and proliferation of cell organelles.

Many studies have described giant cells and feeding sites induced by a given Meloidogyne sp. in numerous host plants. Moreover, some studies have reported different numbers of nuclei per mature giant cell in different host plant-root-knot nematode combinations, i.e., 40 nuclei per giant cell were induced by M. javanica in faba bean (Vicia faba) (3), 50 to 100 nuclei per giant cell by $M$. incognita in sweet potato (Ipomoea batatas) (23), and as many as 150 nuclei per giant cell by $M$. incognita in soybean (Glycine max) (12). However, no study has compared giant cells and feeding sites induced by a range of Meloidogyne spp. in the same host plant.

Chickpea (Cicer arietinum) is one of the most important food legumes grown in the Mediterranean Basin and worldwide (29) and is a promising alternative crop for rotations with barley (Hordeum vulgare), peas (Pisum sativum), and wheat (Triticum aestivum) in dryland areas (1). Infection of chickpea roots by Meloidogyne spp. reduces plant growth and yield and may impair valuable resistance to the Fusarium wilt pathogen, Fusarium oxysporum f. sp. ciceris $(8,36)$. Whereas $M$. arenaria, $M$. incognita, and $M$. javanica are the principal root-knot nematodes infecting chickpeas in the Indian subcontinent (30), chickpea crops in the Mediterranean Basin are attacked mainly by the cereal and legume root-knot nematode, $M$. artiellia, which causes severe yield 
losses $(9,15,35)$. M. artiellia also parasitizes and damages cereals (except corn and oat), crucifers, and legumes (except lentils) (11), many of which are extensively cultivated in the Mediterranean Basin.

The objectives of this research were to (i) qualitatively and quantitatively compare feeding sites induced by isolates of $M$. arenaria, $M$. artiellia, $M$. incognita, and $M$. javanica in chickpea cv. UC 27; and (ii) examine the response of rapeseed (Brassica napus var. oleifera) and faba bean cv. Minor to infections by an isolate of $M$. artiellia.

\section{MATERIALS AND METHODS}

Nematodes. This study used eight isolates of root-knot nematode, including five of $M$. artiellia and one each of $M$. arenaria, $M$. incognita, and $M$. javanica. The five isolates of $M$. artiellia originated from chickpea soils: $M a-\mathrm{S} 1, M a-\mathrm{S} 2$, and $M a-\mathrm{S} 3$ were collected at Alhama de Granada (Granada), southern Spain; $M a-\mathrm{I}$ was from Gravina (Bari), southern Italy; and $M a$-Sy was from Tel-Hadya, Syria. These isolates are representative of those occurring in the Mediterranean chickpea-growing areas $(15,16,33)$. Isolates of $M$. arenaria race 2 (Mar-2), $M$. incognita race 1 (Mi-1), and $M$. javanica $(M j)$ were selected from the nematode collection of the Institute of Sustainable Agriculture, Córdoba, Spain, as representative of root-knot nematodes of temperate to subtropical environments. The Mar-2, $M i-1$, and $M j$ isolates originated from southern Spain in La Carlota (Córdoba), Villaverde del Río (Seville), and Alcolea (Córdoba), respectively.

To establish and maintain cultures of the Meloidogyne spp., surface-disinfested $(2 \% \mathrm{NaOCl}$ for 3 min) seeds of chickpea cv. UC 27 were sown in $15-\mathrm{cm}$-diameter clay pots filled with 0.5 liters of soil infested with the appropriate nematode species. Plants were incubated in a growth chamber adjusted to $24 \pm 1^{\circ} \mathrm{C}$ and a 14-h photoperiod of fluorescent light at $360 \pm 25 \mu \mathrm{E} \mathrm{m}^{-2} \mathrm{~s}^{-1}$ for 2 to 3 months. Plants were watered as needed and fertilized weekly with a water soluble fertilizer containing nitrogen, phosphorus, potassium, and micronutrients.

To produce nematode inocula for experiments, a single egg mass of each nematode isolate was aseptically removed from a gall containing a single nematode female in infected chickpea roots, surface-disinfested with $1 \% \mathrm{NaOCl}$ for 4 min, and washed four times in sterile distilled water. The disinfested egg mass was placed onto roots of a 2- to 3-week-old 'UC 27' chickpea plant grown in a sterile soil mixture (sand/clay loam, 2:1, vol/vol), and plants were grown as described previously for 3 to 4 months. These infected plants provided the nematode inocula, consisting of eggs and $\mathrm{J} 2$ extracted according to the $\mathrm{NaOCl}$ procedure (19), for experiments.

Histopathological studies. Two experiments (I and II) were conducted in a growth chamber under the controlled conditions described previously. These environmental conditions are optimal for the development and reproduction of Meloidogyne spp. (10,27).

Experiment I determined the responses of 'UC 27' chickpea roots to infections by the eight Meloidogyne isolates. For that purpose, seeds of chickpea cv. UC 27 were surface-disinfested as described previously and germinated on sterile, moistened filter paper in petri dishes at $25^{\circ} \mathrm{C}$ in the dark for $48 \mathrm{~h}$. Germinated seeds, selected for uniformity (1- to 2-cm-long radicles), were sown in $15-\mathrm{cm}$-diameter clay pots (one seed per pot) filled with 0.5 liters of the same sterile potting mixture used for inoculum increase. Seedlings were inoculated by adding nematodes $(1,000$ eggs $+\mathrm{J} 2$ of each nematode isolate) in $5 \mathrm{ml}$ of sterile distilled water onto the seed at sowing. Sterile distilled water $(5 \mathrm{ml})$ without the nematode was added in the control treatment. There were nine inoculation treatments replicated six times in a completely randomized design, each replicate consisting of a single potted plant.
Thirty days after inoculation, roots were gently washed free of adhering soil and debris and cut into 2- to 3-cm-long segments. Four root segments from each infected plant were arbitrarily selected for histopathological observations, thus providing 24 root segments for each plant-nematode combination. Each root segment included an individual gall that was assumed to contain only one female, as well as adjacent portions of nonswollen root tissue. Four root segments were also obtained from noninoculated control plants. The root segments were fixed in formaldehyde chromo-acetic solution for $48 \mathrm{~h}$, dehydrated in a tertiary butyl alcohol series (40-70-85-90-100\%), and embedded in $58^{\circ} \mathrm{C}$ melting point paraffin. Embedded tissues were cut into $20-\mu \mathrm{m}-$ thick cross sections with a rotary microtome, and the sections were placed on glass slides, stained with safranin and fast-green (21), and mounted permanently in $40 \%$ xylene solution of a polymethacrylic ester (Synocril 9122X, Cray Valley Products, NJ).

A gall diameter index was determined for each sampled root segment. The gall diameter index was the widest diameter of the swollen root tissue divided by the diameter of the adjacent nonswollen root tissue. For the histopathological study, microscopic observations and measurements were performed on a cross section of each root segment at its point of maximum root gall expansion. The following parameters were determined: (i) giant cell-stelar $\%=$ the total area of all giant cells at a feeding site divided by the total area of the vascular cylinder in the same section times 100; (ii) number of giant cells per feeding site; (iii) area of each giant cell in the feeding site; (iv) number of nuclei per giant cell; and (v) maximum diameter of each nucleus and nucleus in each giant cell. The measurements were made with an image analysis system (Leica Microsystems QWIN 550IW, Cambridge, UK) connected to an optical microscope at magnification of $\times 100$ to $\times 400$. This system was also used to record the microscope images for presentation.

Experiment II aimed to confirm the qualitative response of two other hosts, rapeseed and faba bean, to infection by $M$. artiellia. Plants of rapeseed and faba bean cv. Minor were inoculated with the $M$. artiellia isolate from Italy $(M a-\mathrm{I})$ as described for experiment I. There were six replicated pots each with a single plant for both rapeseed and faba bean. Noninoculated control plants were treated similarly to those of experiment I. Plants were grown and root tissue was sampled and observed as described for experiment I, i.e., four root segments were collected per plant and one cross section was examined per segment, but no quantitative measurements were performed on the cross sections.

Statistical analysis. Experiments I and II were each performed once. Quantitative data obtained from examination of cross sections of experiment I were subjected to analysis of variance using Statistix 8.0 (NH Analytical Software, Roseville, MN). Means values were compared using Fisher's protected least significant difference test at $P=0.05$ (14). Data from experiment II were not quantitative and therefore could not be statistically analyzed.

\section{RESULTS}

No symptoms developed in roots of noninoculated control plants in experiments I or II. In experiment I, all Meloidogyne isolates infected 'UC 27' chickpeas and induced root galls; gall size (Fig. 1) and gall diameter index (Fig. 2A) differed $(P<$ 0.001 ) among the Meloidogyne species. The gall diameter indexes of $M$. arenaria, $M$. incognita, and $M$. javanica did not differ from each other, but they were larger $(P<0.001)$ than those of $M$. artiellia (Fig. 2A). There were no significant differences among gall diameter indexes induced by the five $M$. artiellia isolates (Fig. 2A). Additionally, adult females of $M$. artiellia protruded from the surface of most infected root segments, while those of other Meloidogyne species remained inside the root tissue (Fig. 1).

Histological observations of infected tissues indicated additional similarities and differences between M. artiellia and the 
other Meloidogyne species (Fig. 3). The giant cells induced by all Meloidogyne isolates were generally quite large, round or oval, and sometimes lobed (Figs. 3 and 4). In M. artiellia-infected roots, the formation of giant cells modified the internal structure of the vascular cylinder; however, giant cell formation did not distort the vascular cylinder's original form or expand into the cortex (Fig. 3B to F), and cortical cells adjacent to the nematode feeding sites did not undergo extensive and disorganized hyperplasia. Conversely, feeding sites induced by isolates of $M$. arenaria, $M$. incognita, or $M$. javanica were characterized by extensive distortion of the vascular cylinder (Fig. 3G to I) as well as hyperplasic disorganization of the root cortex.

Feeding sites induced by all Meloidogyne isolates occupied extensive areas of the vascular cylinder including xylem, phloem, and associated parenchymatic tissues (Fig. 3). In some cases, the feeding site induced by $M$. artiellia isolates constituted almost the entire vascular cylinder (Fig. 3C and F). In spite of the apparent variability in the feeding site morphology, there were no significant differences $(P=0.176)$ in the relative area of feeding sites induced by the several Meloidogyne isolates in the study, as determined by the giant cell-stelar \% (Fig. 2B). Similarly, the mean number of giant cells per feeding site (Fig. 2C) as well as the mean area per giant cell did not differ $(P=0.656$ and 0.268 , respectively) among the Meloidogyne isolates and species (Fig. 2D).

The number, distribution, and size of nuclei in giant cells differed among Meloidogyne species (Figs. 2 to 4). M. artielliainduced giant cells contained many fewer nuclei $(P<0.001)$ than in giant cells induced by other Meloidogyne species (Figs. 2 to 4). Also, nuclei in most giant cells induced by $M$. artiellia isolates were round and substantially larger $(P<0.001)$ than nuclei in giant cells induced by isolates of other Meloidogyne spp. (Figs. 2 to 4). Furthermore, nuclei in $M$. artiellia-induced feeding sites tended to aggregate in the center of the giant cells (Fig. 4).

The nuclei in giant cells induced by $M$. arenaria, $M$. incognita, and $M$. javanica isolates were also round to oval, but quite numerous, small, and scattered throughout the giant cell cytoplasm (Fig. 4G to I). The mean number of nuclei per giant cell was greater $(P<0.001)$ with $M$. javanica than with $M$. arenaria or $M$. incognita (Figs. 2 and 4). Conversely, the average maximum diameter of nuclei in giant cells was smaller $(P<0.001)$ with $M$. javanica than with $M$. arenaria or M. incognita (Figs. 2 and 4).

Nucleolar characteristics were similar to those described for nuclei. Nucleoli in $M$. artiellia-induced giant cells were larger $(P<0.001)$ than nucleoli in giant cells induced by the other Meloidogyne species (Fig. 4). The nucleolar diameter in giant cells did not differ among $M$. arenaria, $M$. javanica, and $M$. incognita, but it was smaller $(P<0.001)$ than that of $M$. artielliainduced giant cells.

Both faba bean and rapeseed plants were infected by $M$. artiellia isolate $M a-\mathrm{I}$ in experiment II. The galling was weak, i.e., external swelling was barely distinguishable. Although no quantitative histopathological measurements were performed, detailed microscopic observations of root cross sections indicated that giant cells induced by $M$. artiellia in faba bean and rapeseed contained a small number (three to five) of large (14 to $18 \mu \mathrm{m}$ in diameter) nuclei, which were usually clustered near the center of the giant cell (Fig. 5).
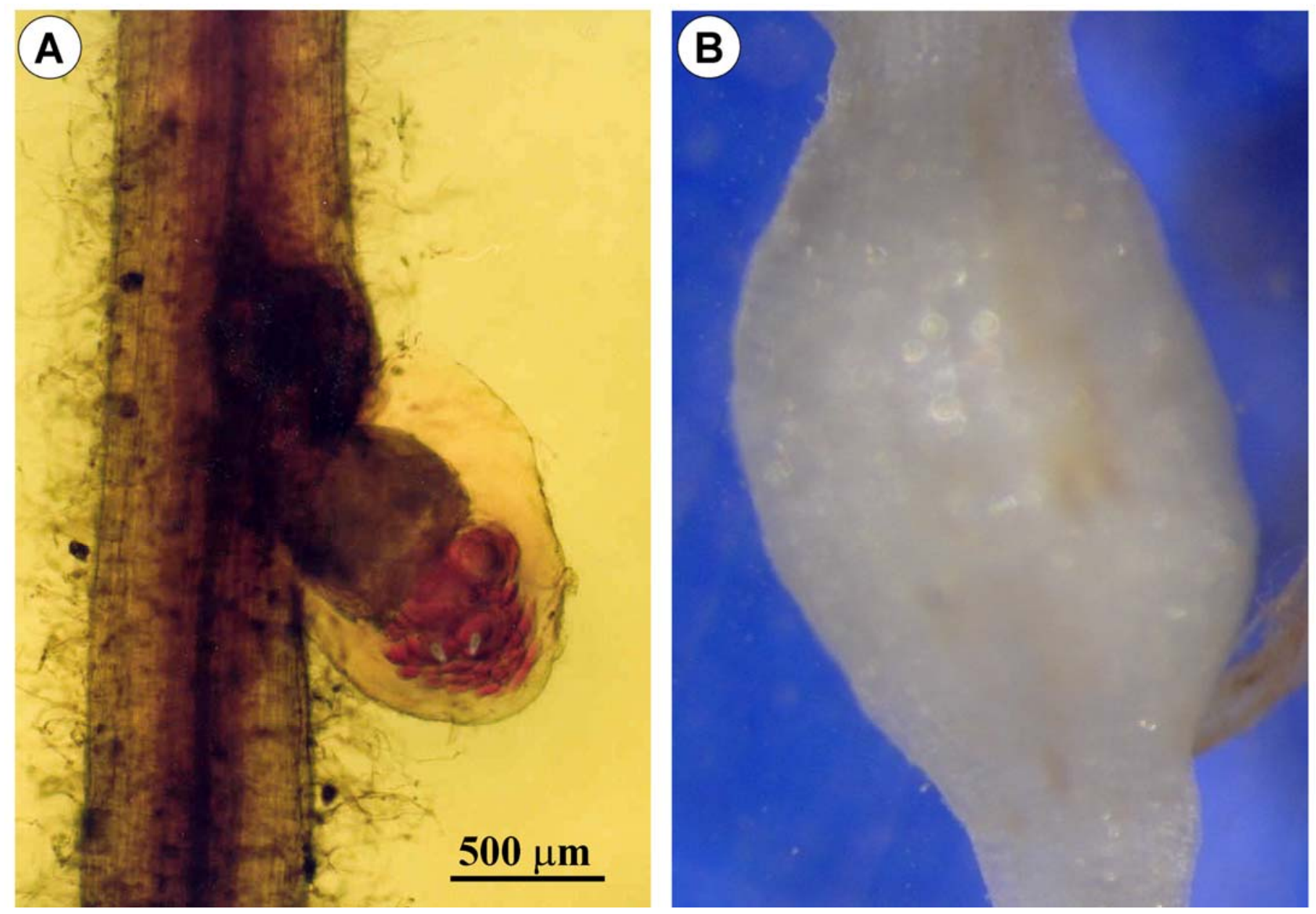

Fig. 1. Galls on roots of 'UC 27' chickpeas infected by A, Meloidogyne artiellia and B, M. incognita. The root tissue was cleared and the nematode stained in A but not in $\mathbf{B}$. The female M. artiellia induces little swelling and protrudes from the gall, whereas the female M. incognita induces large galls and remains within the root tissue. 


\section{DISCUSSION}

The main purpose of this work was to qualitatively and quantitatively compare the histopathological changes in the feeding sites induced by four Meloidogyne species (M. arenaria, M. artiellia, $M$. incognita, and $M$. javanica) in chickpea cv. UC 27. Knowledge from our study complements that from others concerning the influence of the host plant species on the size and general appearance of galls and giant cells, as well as on the number of nuclei per giant cell induced by Meloidogyne spp. $(17,32)$. The validity and repro- ducibility of our results are supported by the use of eight different Meloidogyne isolates, representing a range of geographical locations and environments. Also, the experiments were conducted under controlled conditions, using an inoculum density small enough to result in galls induced by single females. All observations and measurements of feeding sites were performed consistently on cross sections in the position of maximum root gall expansion, so that the relative values obtained are certainly valid. However, since the nematode feeding site is three-dimensional, some of its structural aspects might have been overlooked in our study.
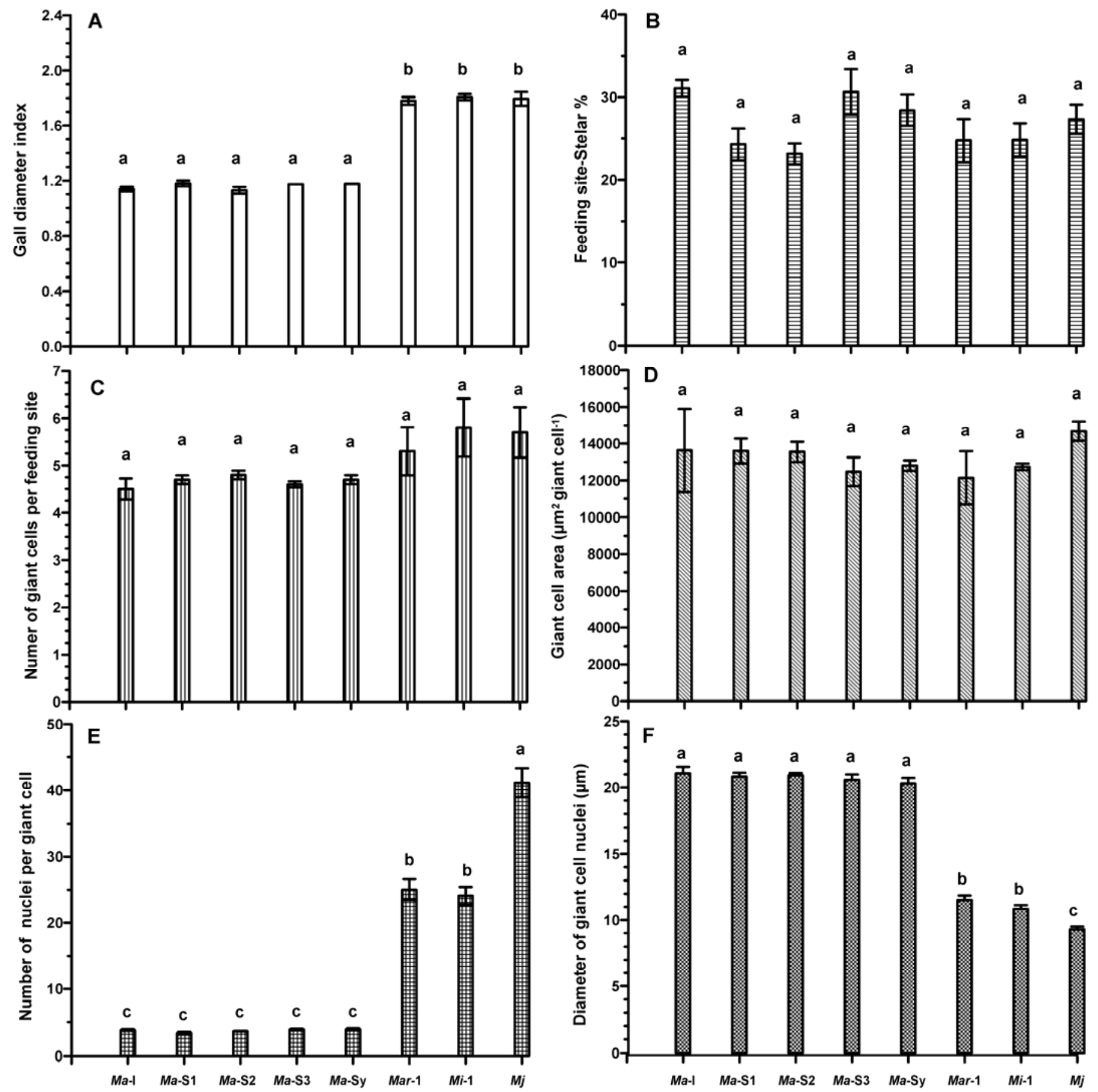

Fig. 2. Characteristics of galls and giant cells in chickpea cv. UC 27 infected by five isolates of Meloidogyne artiellia (Ma-I, Ma-S1, Ma-S2, Ma-S3, and $M a-\mathrm{Sy})$ or one isolate each of M. arenaria (Mar-2), M. incognita (Mi-1), and M. javanica (Mj). Measurements and observations were performed on cross sections of root segments at the site of maximum root gall expansion. A, Gall diameter index $=$ the widest diameter of the swollen root tissue divided by the diameter of the adjacent healthy root tissue. B, Giant cell-stelar $\%=$ the total area of all giant cells at a feeding site divided by the total area of the vascular cylinder in the same section times 100. C, Number of giant cells per feeding site. D, Giant cell area. E, Number of nuclei per giant cell. F, Diameter of giant cell nuclei. Each value is the mean ( \pm standard error) of six replicate plants (four galls per plant). Bars followed by common letters do not differ significantly $(P>0.05)$ according to Fisher's protected least significant difference test. 

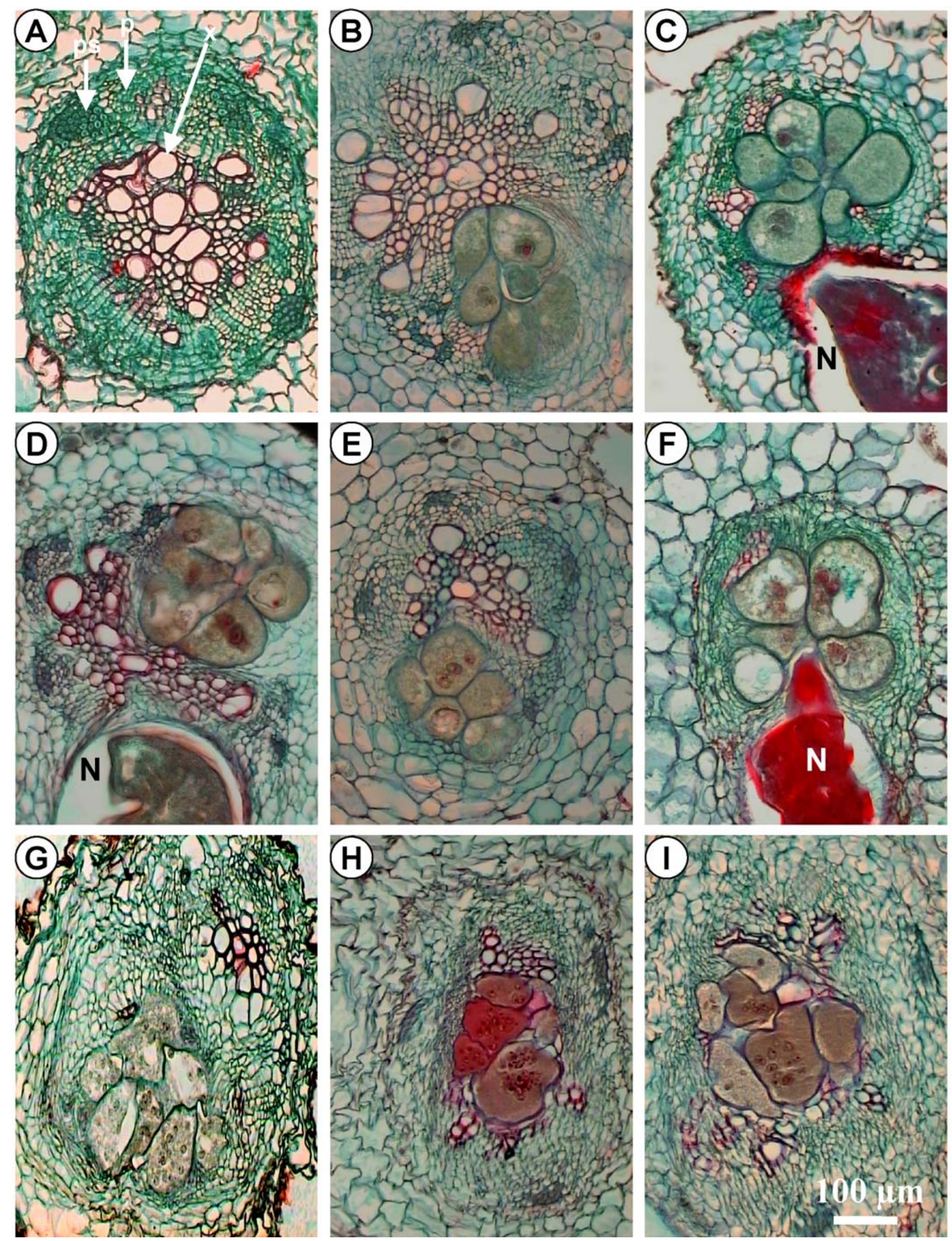

Fig. 3. Light micrographs of root tissue (chickpea 'UC 27' cross sections) either A, uninfected or infected by Meloidogyne artiellia isolate B, Ma-I, C, Ma-S1, D, Ma-S2, E, Ma-S3, F, Ma-Sy; G, M. arenaria; H, M. incognita; or I, M. javanica. A, Arrows indicate protoxylem elements and phloem and parenchymatous cells. $\mathrm{N}=$ adult female nematode. 

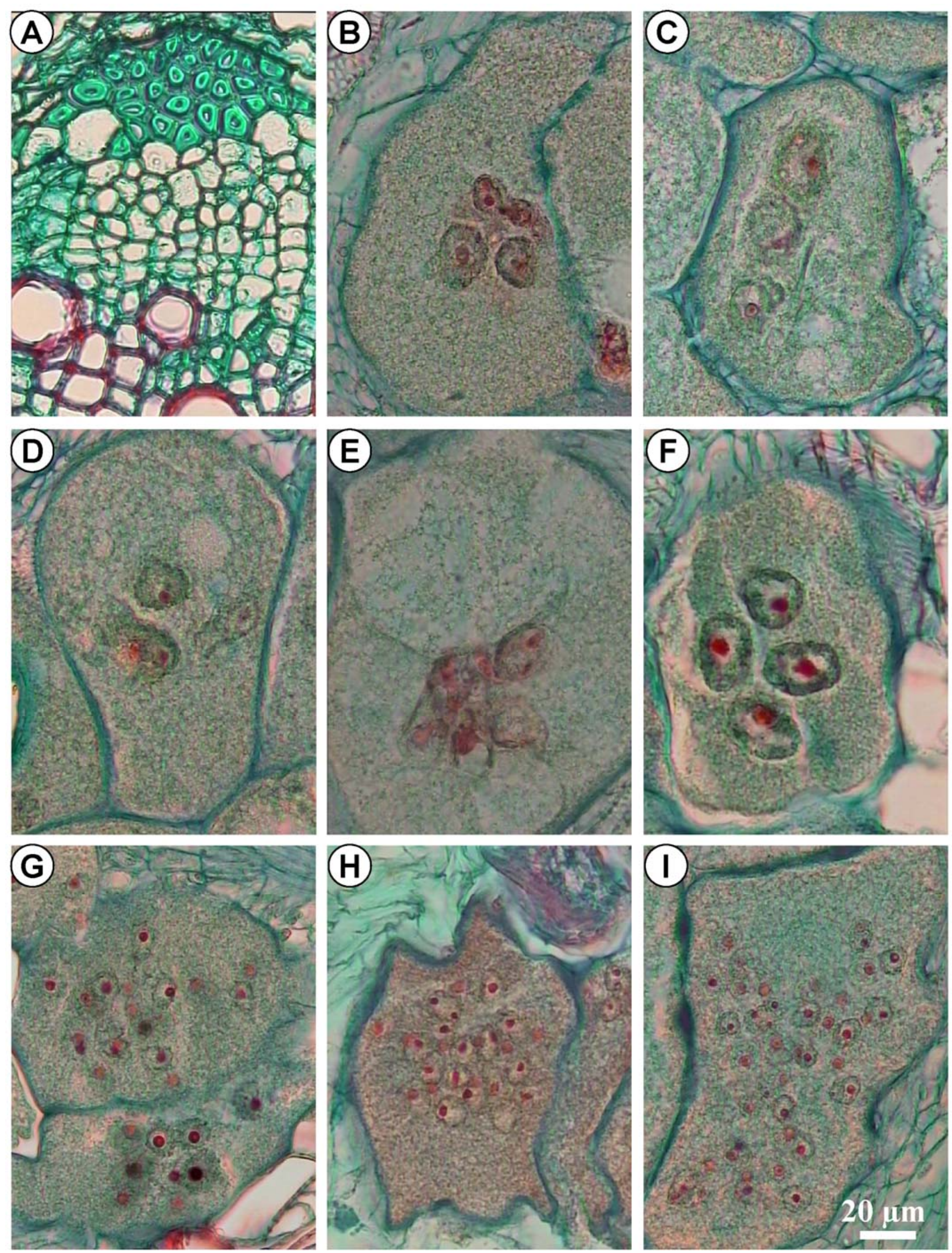

Fig. 4. High magnification light micrographs of root tissue (chickpea 'UC 27' cross sections) either A, uninfected or infected by Meloidogyne artiellia isolate B, Ma-I, C, Ma-S1, D, Ma-S2, E, Ma-S3, F, Ma-Sy; G, M. arenaria $; \mathbf{H , ~ M . ~ i n c o g n i t a ; ~ o r ~ I , ~ M . ~ j a v a n i c a . ~}$ 
Compared with $M$. arenaria, $M$. incognita, and $M$. javanica, all of which produced large galls on chickpea, $M$. artiellia produced small galls or no galls. The limited hyperplasia in the vascular cylinder and the cortical cells around the feeding site seem to be related to the small gall size. The frequently observed protrusion of bodies of adult $M$. artiellia females from the infected roots, resembling the parasitic habit of adult cyst-nematode females, was congruent with that lack of root gall swelling. A similar difference in root gall development has been reported for M. marylandi and $M$. naasi infecting wheat $(25,26)$. In our study, however, neither the number nor size of giant cells induced in chickpea were influenced by the nematode isolate or species, which suggests that this host species is well suited to satisfy the parasitic needs of all of them. This interpretation is consistent with the idea that host plant species rather than Meloidogyne sp. determines the number and size of giant cells (40).

Like $M$. artiellia-induced giant cells in chickpea, $M$. artielliainduced giant cells in faba bean or rapeseed also contained a small number of large nuclei. A preliminary report described similar results when the host plant was cabbage (B. oleracea) or turnip (B. rapa) (24). Also, with tobacco, Sosa-Moss et al. (31) found small numbers of nuclei in $M$. hapla giant cells and large numbers in $M$. arenaria, $M$. incognita, and $M$. javanica giant cells. In addition, both our data and previous reports suggest that Meloidogyne spp. development can proceed with small numbers of nuclei within a giant cell, as hypothesized by Wiggers et al. (39).

Previous studies have reported that the number of nuclei in giant cells induced by a particular Meloidogyne species in a given host plant tends to vary considerably $(3,23,40)$. Contrary to that, the number of nuclei per giant cell in our study showed low variation. That could be related to the specific plant-nematode combinations we studied, but also may indicate that the 30-day incubation period was long enough to allow for major nuclear division activity.

At this time, the significance of $M$. artiellia inducing giant cell nuclei that are unusually few in number and large in size is unclear. Although we don't know which factor(s) controls nuclei number and size in giant cells, we suggest that $M$. artiellia may induce fewer nuclear divisions than do other Meloidogyne spp. Differences in number of nuclei could reflect differences in the ability of giant cells to produce tubulin for synthesis of spindle fibers or for the attachment of spindle fibers to the kinetochore $(2,32)$.

As suggested by Wiggers et al. (38), the number of nuclei in Meloidogyne-induced giant cells should be the result of a regular mathematical progression of nuclear division, with possible variations due to abnormal divisions of genetic material. In our study, we carefully controlled inoculation and incubation conditions so that all induced giant cells, and therefore the giant cell nuclei, would be of similar age. Consequently, the numerical differences in giant cell nuclei number and size should be attributable mainly to the nematode species, with no or minor timing effect. The logic of this reasoning is supported by observations that mitosis in giant cells occurs after the Meloidogyne $\mathrm{J} 2$ molts, and the maximum mitotic activity occurs mainly during the first stages of infection by the nematode, approximately 7 to 10 days after inoculation $(3,18)$. Differences in the size of giant cell nuclei were attributed by Huang and Maggenti (18) to irregular fusions of neighboring metaphase plates, uneven distribution of chromosome sets at anaphase resulting from lack of spindle orientations, or incomplete migration of chromosomes at anaphase.

All Meloidogyne spp. in the study, irrespective of their host range, induced giant cells of similar size and form, suggesting that consistent nematode genes and plant genes are involved in giant cell formation (7). Mature giant cells are metabolically highly active sinks of nutrients for the nematode, as suggested by the presence of aneuploid nuclei containing 14 to 16 times more DNA than root tip nuclei of uninfected plants (38). However, our findings reveal that giant cell development may proceed differently in a host plant when infected by different root-knot nematode species. Even though all Meloidogyne spp. in the study developed at the same rate (mature females were present in all cases), the number and characteristics of nuclei in giant cells differed significantly among nematode species.

After decades of research, the signals responsible for the induction and maintenance of giant cells are still unknown (6). Because two genes (PHANTASTICA and KNOTTED1) expressed in giant cells have been implicated in the formation and maintenance of plant meristems $(22,34,37)$, researchers have recently suggested that the giant cell could be a kind of induced meristem. Koltai and Bird (22) proposed that expression of those genes in giant cells may relate to alterations in cytokinin and auxin levels, in agreement with the observed production of biologically active cytokinin by Meloidogyne spp. (4) and the proposed function of cytokinin as a primary inductive signal for giant cells formation (5). The differences we observed in giant cell nuclei induced by different Meloidogyne species might provide a tool for further exploration of mechanisms involved in giant cell induction and maintenance. Also, future studies should determine whether the DNA content of giant cell nuclei varies for different feeding site responses, depending on the nematode-host plant combination. A
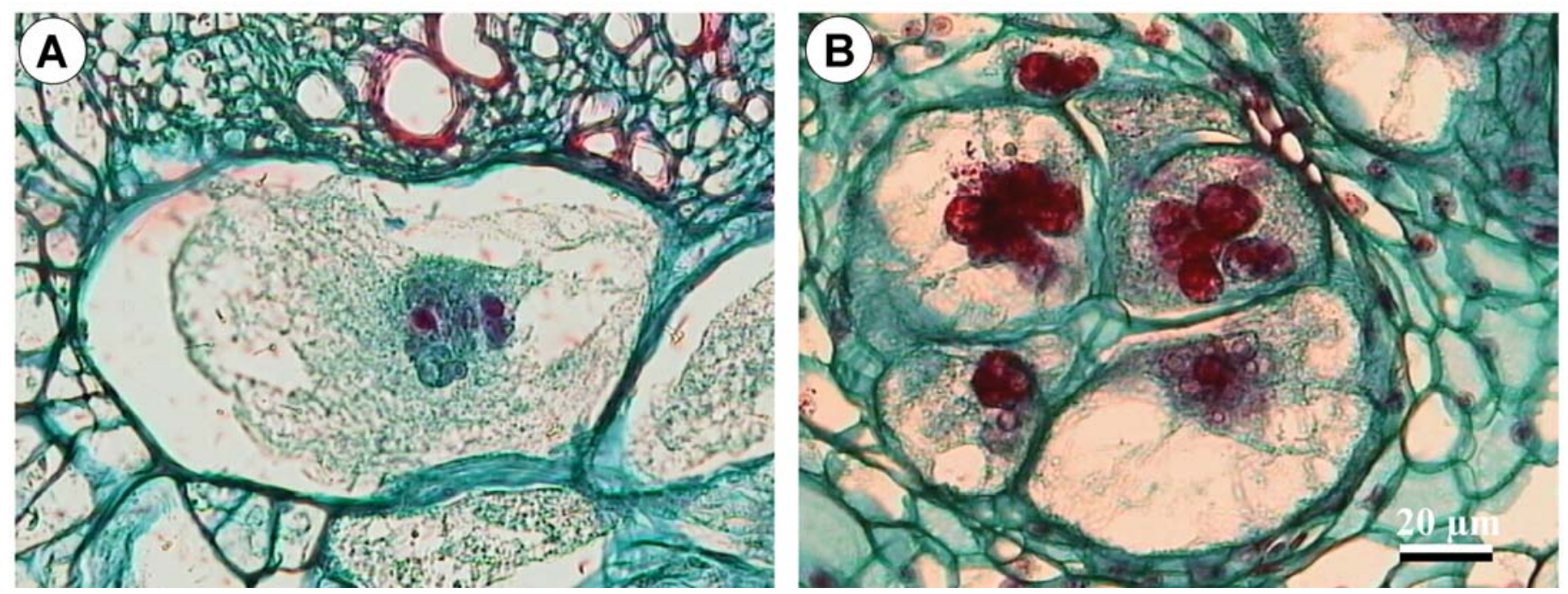

Fig. 5. Light micrographs of giant cells induced by Meloidogyne artiellia (isolate Ma-I) in A, rapeseed (var. oleifera) and B, faba bean (cv. Minor). 
pattern is emerging with respect to the relative roles of host plant and nematode species in determining the nature of the feeding site induced by Meloidogyne spp. From our findings, we suggest that root gall swelling depends on the nematode species, whereas giant cell number and size might relate to host plant species and nuclear characteristics in giant cells could be related to nematode species.

\section{ACKNOWLEDGMENTS}

This research was supported by grant AGL2003-00640 from Comisión Interministerial de Ciencia y Tecnología (CICYT), Ministerio Educación y Ciencia of Spain. We thank J. Martín-Barbarroja and V. HernándezFernández (IAS-CSIC) and A. Brandonisio (IPP-Bari, Italy) for technical assistance and the anonymous reviewers for suggestions.

\section{LITERATURE CITED}

1. Auld, D. L., and Lee, C. A. 1981. Chickpeas: A potential new pulse crop for northern Idaho. Univ. Idaho Coop. Ext. Serv. Curr. Inf. Ser. 570.

2. Bajer, A. 1968. Behavior and fine structure of spindle fibers during mitosis in endosperm. Chromosoma 25:249-281.

3. Bird, A. F. 1973. Observations on chromosomes and nucleoli in syncytia induced by Meloidogyne javanica. Physiol. Plant Pathol. 3:387-391.

4. Bird, A. F., and Loveys, B. R. 1980. The involvement of cytokinins in a host-parasite relationship between the tomato (Lycopersicon esculentum) and a nematode (Meloidogyne javanica). Parasitology 80:497-505.

5. Bird, D. M. 1996. Manipulation of host gene expression by root-knot nematodes. J. Parasitol. 82:881-888.

6. Bird, D. M. 2004. Signaling between nematodes and plants. Curr. Opin. Plant Biol. 7:1-5.

7. Blok, V. C., Ehwaeti, M., Fargette, M., Kumar, A., Phillips, M. S., Robertson, W. M., and Trudgill, D. L. 1997. Evolution of resistance and virulence in relation to the management of nematodes with different biology, origins and reproductive strategies. Nematologica 43:1-13.

8. Castillo, P., Navas-Cortés, J. A., Gomar-Tinoco, D., Di Vito, M., and Jiménez-Díaz, R. M. 2003. Interactions between Meloidogyne artiellia, the cereal and legume root-knot nematode, and Fusarium oxysporum $\mathrm{f}$. sp. ciceris race 5 in chickpea. Phytopathology 93:1513-1523.

9. Di Vito, M., and Greco, N. 1988. The relationship between initial population densities of Meloidogyne artiellia and yield of winter and spring chickpea. Nematol. Mediterr. 16:163-166.

10. Di Vito, M., and Greco, N. 1988. Investigation on the biology of Meloidogyne artiellia. Rev. Nématol. 11:223-227.

11. Di Vito, M., Greco, N., and Zaccheo, G. 1985. On the host range of Meloidogyne artiellia. Nematol. Mediterr. 13:207-212.

12. Dropkin, V. H., and Nelson, P. E. 1960. The histopathology of root-knot nematode infections in soybean. Phytopathology 50:442-447.

13. Eisenback, J. D., and Triantaphyllou, H. H. 1991. Root-knot nematodes: Meloidogyne species and races. Pages 191-274 in: Manual of Agricultural Nematology. W. R. Nickle, ed. Marcel Dekker, New York.

14. Gomez, K. A., and Gomez, A. A. 1984. Statistical Procedures for Agricultural Research. 2nd ed. John Wiley \& Sons, New York.

15. Greco, N. 1984. Presenza di Meloidogyne artiellia su cece in Italia. Nematol. Mediterr. 12:235-238

16. Greco, N., Di Vito, M., Reddy, M. V., and Saxena, M. C. 1984. A preliminary report of survey of plant parasitic nematodes of leguminous crops in Syria. Nematol. Mediterr. 12:87-93.

17. Huang, C. S. 1985. Formation, anatomy and physiology of giant cells induced by root-knot nematodes. Pages 155-164 in: An Advanced Treatise on Meloidogyne. Vol. I, Biology and Control. J. N. Sasser and C. C. Carter, eds. North Carolina State University Graphics, Raleigh, NC.

18. Huang, C. S., and Maggenti, A. R. 1969. Mitotic aberrations and nuclear changes of developing giant cells in Vicia faba caused by root-knot nematode, Meloidogyne javanica. Phytopathology 59:447-455.
19. Hussey, R. S., and Barker, K. R. 1973. A comparison of methods of collecting inocula of Meloidogyne spp., including a new technique. Plant Dis. Rep. 57:1025-1028.

20. Hussey, R. S., and Williamson, V. M. 1997. Physiological and molecular aspects of nematode parasitism. Pages 87-108 in: Plant and Nematode Interactions. K. R. Barker, G. A. Pederson, and G. L. Windham, eds. American Society of Agronomy, Madison, WI.

21. Johansen, D. A. 1940. Plant Microtechnique. McGraw-Hill Book Co., New York and London.

22. Koltai, H., and Bird, D. M. 2000. Epistatic repression of PHANTASTICA and class 1 KNOTTED genes is uncoupled in tomato. Plant J. 22:455459.

23. Krusberg, L. R., and Nielsen, L. W. 1958. Pathogenesis of root-knot nematodes to the Porto Rico variety of sweet potato. Phytopathology 48:30-39.

24. Mor, M. 2002. Comparative histology of feeding sites of Meloidogyne artiellia and M. javanica. (Abstr.) Nematology 4:234.

25. Oka, Y., Karssen, G., and Mor, M. 2003. Identification, host range and infection process of Meloidogyne marylandi from turf grass in Israel. Nematology 5:727-734.

26. Rivoal, R., and Cook, R. 1993. Nematode pests of cereals. Pages 259-303 in: Plant Parasitic Nematodes in: Temperate Agriculture. K. Evans, D. L. Trudgill, and J. M. Webster, eds. CAB International, Wallingford, UK.

27. Roberts, P. A., and Van Gundy, D. 1981. The development and influence of Meloidogyne incognita and M. javanica on wheat. J. Nematol. 13:345352.

28. Sasser, J. N., and Freckman, D. W. 1987. A world perspective on Nematology: The role of the society. Pages 7-14 in: Vistas on Nematology. J. A Veech and D. W. Dickson, eds. Society of Nematologists, Hyattsville, MD.

29. Saxena, M. C. 1990. Problems and potential of chickpea production in the nineties. Pages 13-27 in: Chickpea in the Nineties: Proc. Int. Workshop Chickpea Improvement, 2nd. International Crops Research Institute for the Semi-Arid Tropics (ICRISAT), Patancheru, India.

30. Sikora, R. A., and Greco, N. 1990. Nematode parasites of food legumes. Pages 181-235 in: Plant Parasitic Nematodes in Subtropical and Tropical Agriculture. M. Luc, R. A. Sikora, and J. Bridge, eds. CAB International, Wallingford, UK.

31. Sosa-Moss, C., Barker, K. R., and Daykin, M. E. 1983. Histopathology of selected cultivars of tobacco infected with Meloidogyne species. J. Nematol. 15:392-397.

32. Starr, J. L. 1993. Dynamics of the nuclear complement of giant cells induced by Meloidogyne incognita. J. Nematol. 25:416-421.

33. Talavera, M., and Tobar Jimenez, A. 1997. Plant parasitic nematodes from unirrigated fields in Alhama, south eastern Spain. Nematol. Mediterr. 25:73-81.

34. Thiery, M. G., Greene, A. E., and Bird, D. M. 1999. The Lycopersicon esculentum ortholog of PHANTASTICA/rough sheath2 (Accession No. AF148934) is expressed in feeding sites induced by root-knot nematodes. Plant Physiol. 120:934.

35. Tobar Jiménez, A. 1973. Nematodes de los secanos de la comarca de Alhama. I. Niveles de población y cultivos hospedadores. Rev. Iber. Parasitol. 33:525-556.

36. Uma Maheshwari, T., Sharma, S. B., Reddy, D. D. R., and Haware, M. P. 1997. Interaction of Fusarium oxysporum f. sp. ciceri and Meloidogyne javanica on Cicer arietinum. J. Nematol. 29:117-126.

37. Waites, R., Selvadurai, H. R. N., Oliver, I. R., and Hudson, A. 1998. The PHANTASTICA gene encodes a MYB transcription factor involved in growth and dorsoventrality of lateral organs in Antirrhinum. Cell 93:779789.

38. Wiggers, R. J., Starr, J. L., and Price, H. J. 1990. DNA content variation in chromosome number in plant cells affected by Meloidogyne incognita and $M$. arenaria. Phytopathology 80:1391-1395.

39. Wiggers, R. J., Thornton, N. T., and Starr, J. L. 2002. The effects of colchicine on number of giant cell nuclei and nematode development in Pisum sativum infected by Meloidogyne incognita. Nematology 4:107109.

40. Yousif, G. M. 1979. Histological responses of four leguminous crops infected with Meloidogyne incognita. J. Nematol. 11:395-401. 